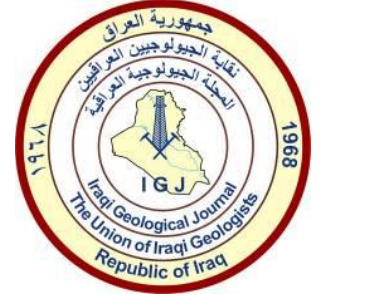

Iraqi Geological Journal

Journal homepage: https://www.igj-iraq.org

\title{
Depositional Environment of the Upper Triassic Baluti Formation in Gara Anticline, Kurdistan Region, North Iraq: Insight from Microfacies and Biomarker Characteristics
}

\author{
Ayad N.F. Edilbi ${ }^{1, ~ *}$, Stephen A. Bowden ${ }^{2}$, Abdala Y. Mohamed ${ }^{2}$ and Govand H. Sherwani ${ }^{3}$ \\ ${ }^{1}$ Department of Petroleum Geosciences, Soran University, Soran, Kurdistan Region, Iraq \\ ${ }^{2}$ Department of Geology and Petroleum Geology, School of Geosciences, University of Aberdeen, Aberdeen \\ ${ }^{3}$ Department of Civil Engineering, Cihan University-Erbil, Erbil, Kurdistan Region, Iraq \\ *Correspondence: ayad.faqi@ soran.edu.iq
}

Received: 1 January 2021; Accepted: 25 March 2021; Published: 31 May 2021

\begin{abstract}
The studied section is located in the core of the Gara Anticline, about $12 \mathrm{~km}$ southeast of Amedi Town. The Baluti Formation is generally composed of grey and green shale, calcareous, dolostone with intercalations of thinly bedded dolostones, dolomitic limestones, and silicified limestones which are occasionally brecciated. The petrographic study shows five main microfacies in the Baluti Formation namely; finely laminated dolomudstone, fossil-barren and lime mudstone, fenestral mudstone/packstone, peloids and ooids wackestone, and lithoclasts (intraclasts) grainstones. The mudstones facies with no fauna and radial-fibrous ooids can point to a protected and low energy environment. Moreover, fenestral structures are reliable criteria for identifying a tidal flat environment. The presence of the lithoclasts (intraclasts) with radial ooids and a few terrestrial fragments may represent a quiet environment, albeit one affected by infrequent storm deposits. As a supplementary to microfacies, the biomarker characterizations were used to deduce the depositional environment of the Baluti Formation. Biomarker parameters show that the Baluti Formation could be deposited in anoxic to suboxic environment, and organic matter input is more likely characterized by land plant organic matter. This study showed that the most likely paleoenvironments for the Baluti Formation were supratidal, intertidal, subtidal, and sand shoals setting. However, the lack and/or very low diversity of skeletal fauna, and the lack of subaerial exposure may indicate that some parts of the formation seem to be deposited in low energy and restricted environment (Lagoon).
\end{abstract}

Keywords: Depositional environment; Baluti; Microfacies; Biomarkers; Kurdistan region; Gara anticline

\section{Introduction}

The studied section (Near Sarki Village, 36 $59^{\prime} 35.39^{\prime \prime} \mathrm{N}, 43^{\circ} 32^{\prime} 22.13^{\prime \prime} \mathrm{E}$ ) is located in the core of the Gara Anticline, about $12 \mathrm{~km}$ southeast of Amedi Town (Fig. 1). Based on the Iraqi Tectonic Divisions, the Gara Anticline is within the High Folded Zone (Fouad, 2015), which is considered as a part of the Unstable Shelf and a part of the Zagros Fold and Thrust Belt (De Vera et al., 2009). Within the Gara Anticline, outcrops can be found representing the Late Triassic, Jurassic, Cretaceous formations of the Kurdistan Region. This is because several formations cropped out at the core of the 
anticline and across its northern limb. The Late Triassic (Upper Kurra Chine and Baluti formations) is found in several places along the core of the Gara anticline to the east, while it disappears towards the west of the anticline. The Baluti Formation is cropping out at different locations surrounding the area, but the section is not seen in its entirety, and even in the studied area drift and cover often hide many sub crops.

According to Hanna (2007), the presence of palynomorphs displays that the environment is more likely influenced by shallow marine conditions. Supratidal and lagoonal to semi-arid tidal flat settings have been proposed by Al-Juboury and McCann (2013). Al-Mashaikie et al. (2016) believed that the Baluti Formation was deposited in a deep marine setting on the northwestern margin of the Gondwana supercontinent. Shingaly (2016) suggested that sediments of the Baluti Formation mainly represent a deep shelf environment. Asaad and Omer (2019) studied diagenetic history and porosity types of the Baluti Formation at the Sarki section. They concluded that the studied section passed through marine, meteoric, burial, and uplift diagenesis. This study aims to determine the depositional environment of the Baluti Formation using microfacies analysis and biomarker characteristics in the Sarki section from Gara Anticline.

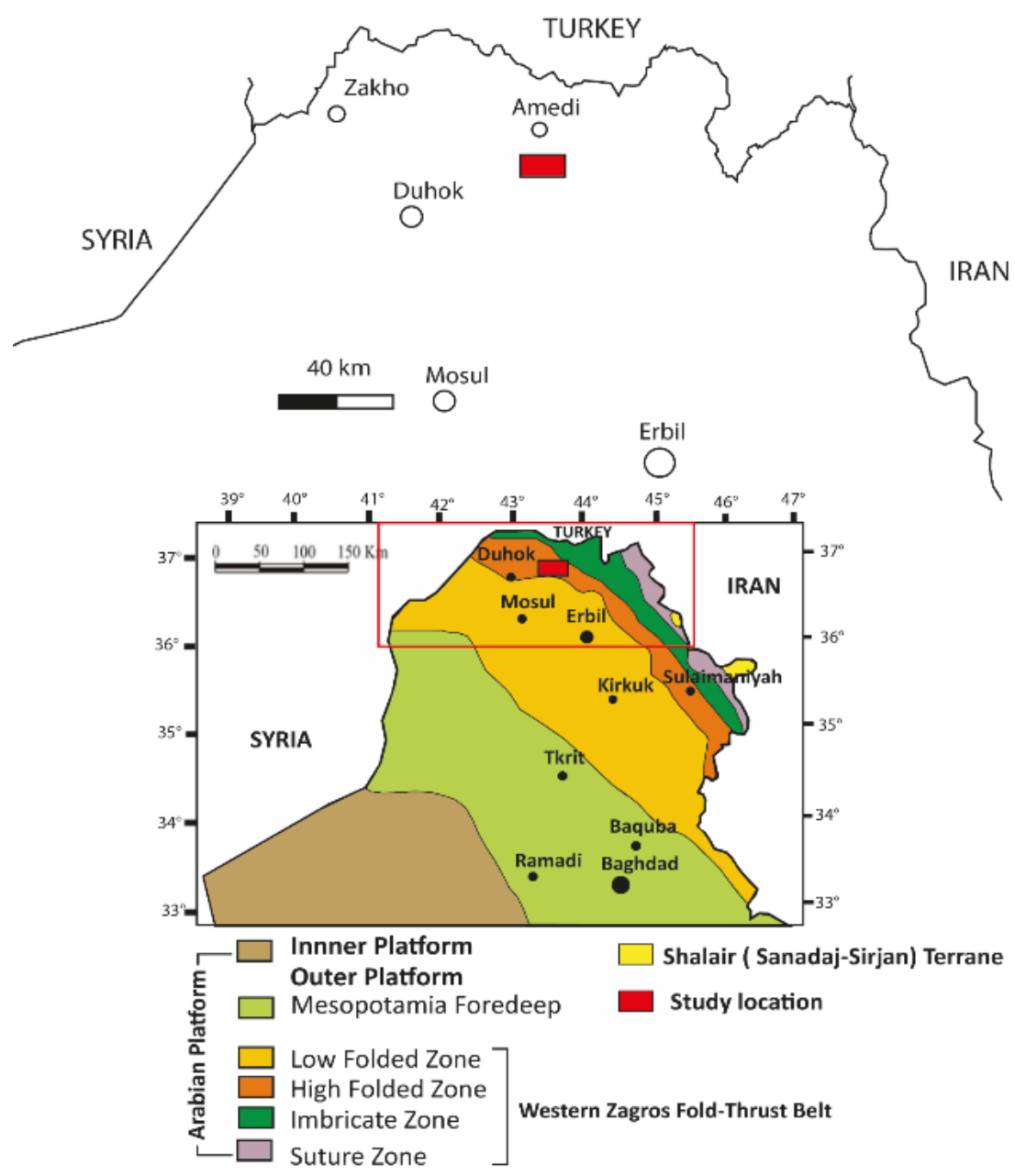

Fig. 1. Location of the study area and tectonic division map of Iraq (maps are modified from Fouad, 2015)

\section{Geological Setting}

Late Triassic-Early Jurassic in the northern part of the Arabian Plate was coincided with rifting which resulted in the creation of new Tethys, meanwhile, the south and south-eastern of the Arabian 
Plate were uplifted then contributed to massive floods of terrigenous clastic to the northeastern parts of that Plate (Jassim et al. 2006). The Kurdistan Region was occupied by the Triassic basin that extended into Syria, Turkey and Iran, but the basin is still largely unknown geographically. The upper part of the Triassic is characterized by calcareous or dolomites sediments exposed in many outcrops in the Kurdistan Region (Bellen et al.1959). The Baluti Formation was first introduced by Wetzel in 1950. The formation`s type section is situated in the core of Gara Anticline. The formation is characterized by grey and green shale, calcareous, dolostone with intercalations of thinly bedded dolostones, dolomitic limestones, and silicified limestones that are partly brecciated (Bellen et al. 1959). They believed that the age of the formation can be Upper Triassic (Rhaetian). The Zor Hauran Formation, in western Iraq, is believed to be equivalent to the Baluti Formation (Buday, 1980; Jassim et al. 2006; Aqrawi et al. 2010). The Baluti Formation was contemporaneously deposited with the strata sequence (AP6) from Middle Permian to the Middle Jurassic of the Arabian plate (Aqrawi et al. 2010). Stratigraphically, the Baluti Formation overlies the Kurra Chine Formation and underlies the Sarki Formation (Fig. 2). Both Lower and upper boundaries of the Baluti Formation are conformable and gradational (Bellen et al. 1959). However, Hanna (2007) believed that the boundary between Baluti and Sarki is unconformable. Based on the ratios of $\mathrm{Mg} / \mathrm{Ca}$ and $\mathrm{Sr} / \mathrm{Ca}$, the shallow marine environment was suggested for Baluti Formation in the Sarki section by Tobia and Mustafa (2019). Lunn et al. (2019) suggested late Carnian (Tuvalian)-early Norian age for the Baluti Formation. The Baluti Formation has a number of lateral equivalents within the region that contribute to petroleum systems.

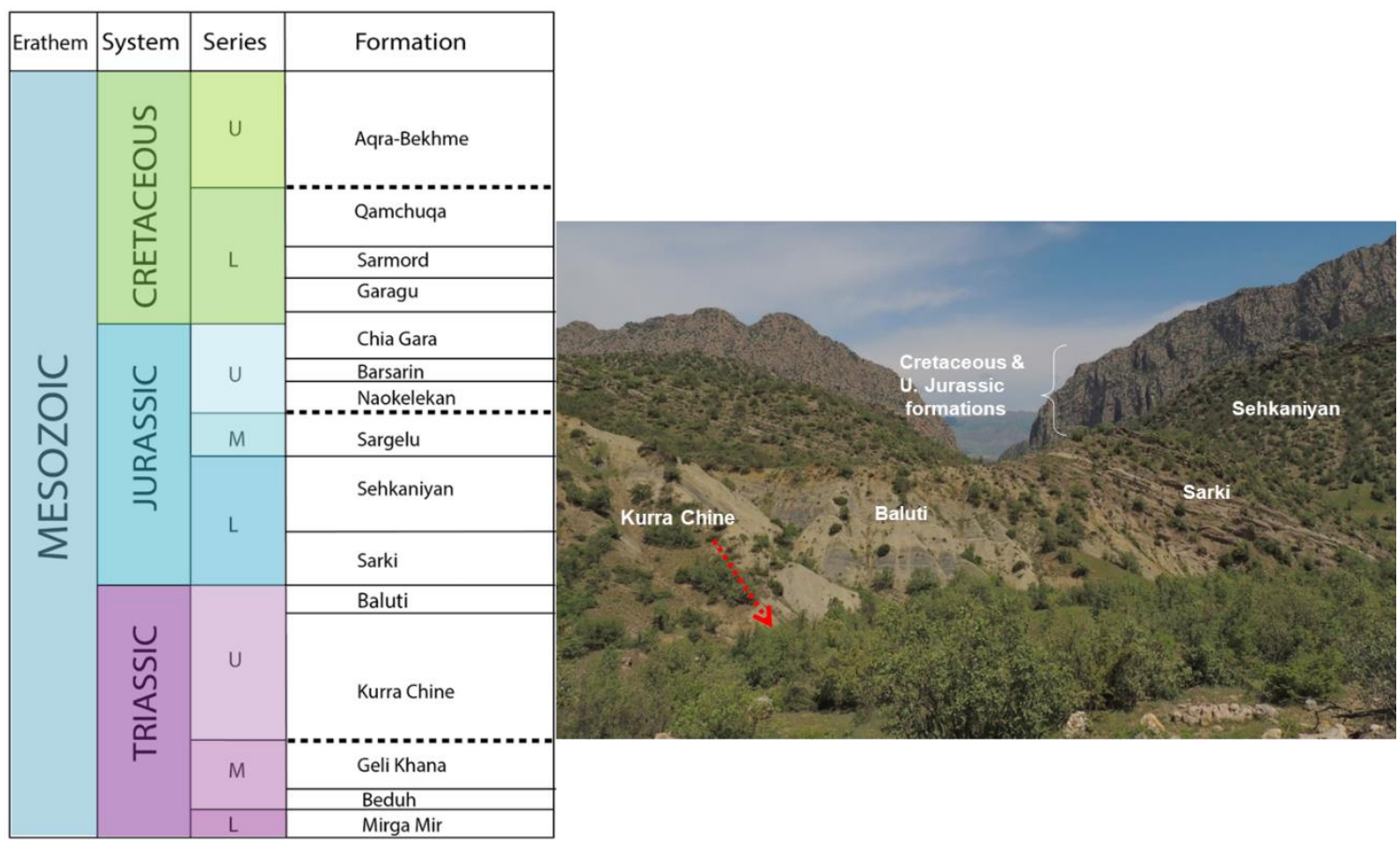

Fig. 2. Stratigraphic column of the Mesozoic of the study area (modified from Al-Badry, 2012 and English et al. 2015). Note: dashed lines represent the hiatus

\section{Materials and Methodology}

\subsection{Field Work}

In order to collect samples and to describe the lithological composition of the Baluti Formation, detailed fieldwork was carried out in two sessions. Sampling was perpendicular to the strike of the beds. 
Thickness and lithology were logged. Then the fresh samples were collected systematically in the field. The 45 samples were collected for organic geochemistry and petrography.

\subsection{Petrography}

Standard thin sections were later prepared in the Department of Petroleum Geology and Geology at the University of Aberdeen-Scotland /the UK. Some of the selected samples were oriented and stained to enable clear identification of carbonate phases. Some special thin sections $(50 \mathrm{~mm} \times 25 \mathrm{~mm}, 30$ microns thickness, impregnated by blue-dyed resin) were also were prepared by ALS. Petrophysics laboratory. The Scheme of modified Dunham's classification (1962) by Embry and Klovan, (1971) was used for study petrography and microfacies analysis.

\subsection{Organic Geochemistry}

Nine samples were selected for Gas Chromatography -Mass Spectrometry (GC-MS). The GC-MS was carried out at the Organic Geochemistry Laboratory, in the Department of Geology and Petroleum Geology at University of Aberdeen. The organic matter was extracted from powdered samples via soxhlet-extraction (samples were extracted for $48 \mathrm{~h}$ using a mixture of dichloromethane and methanol 93:70 v: v). Extracts were fractionated into saturated, aromatic, and polar compounds by silica gel column chromatography. The biomarker data referred to in the text was obtained from saturate fractions that were analyzed by GC-MS. GC-MS was carried out with an Agilent Technologies (AT) $6890 \mathrm{~N}$ Network GC (pulsed spitless) system fitted with a $30.0 \times 250.0 \mu \mathrm{m}$ i.d, film thickness $0.25 \mu \mathrm{m}$ fused silica column coated with DB-5 coupled to an AT 5975 quadrupole mass selector detector (electron energy $70 \mathrm{eV}$, source $250^{\circ} \mathrm{C}$ ) with Helium as carrier gas. The $\mathrm{GC}$ temperature program for saturated hydrocarbons was hold at $60{ }^{\circ} \mathrm{C}$ for $2.0 \mathrm{~min}$, rising at $20{ }^{\circ} \mathrm{C} \mathrm{min}-1$ to $120{ }^{\circ} \mathrm{C}$, and then rising at 4 ${ }^{\circ} \mathrm{Cmin}-1$ to $290{ }^{\circ} \mathrm{C}$ and then holding for $23 \mathrm{~min}$.

\section{Results}

\subsection{Field Observation}

Within the studied section, the first marl bed can be clearly identified but due to tectonic activity subsequent beds are often unclear or missing. As a consequence, much logging was carried out offset from the basal marl beds of the lower part of the Baluti. Based on field observations, the formation can be divided into three facies according to the prevalence of key lithologies. The lower part of the formation (about $19.25 \mathrm{~m}$ thick) is composed of marls which are intercalated with dolomitic limestones and marly limestones. The lowermost part of the formation is characterized by grey, olive-green to buff and hard marl sediments that are followed by a few medium-thickly bedded marly limestones, dolomites and limestones (Fig. 4). About two meters of this unit comprises limestones and dolomitic limestones that are yellow in color, highly brecciated, fractured and veined. The veins contain small and large crystals of calcite. The broken limestone has a box-work structure and the large pores are filed with yellowish clay and marl (Fig. 3a). About 3 meters of this unit is obscured by soils, vegetation and locally derived drift and regolith. Next follows an interval with stratigraphic thickness of 1.70 meter of marls, limestones and marly limestone. Then a thick layer of the mudstone (1.4-meter-thick) from the middle part can be seen. The middle part of the formation, about 31.75 meters thick, is more dominated by dark mud rocks than its other parts. These mud rocks are also intercalated with dolomitic limestones and limestones. The thickness of the mudstone is usually variable; it ranges from $30 \mathrm{~cm}$ up to 2 meters or more (Fig.4). The weathered surface of the dolomitic limestones is grey to white in color, while the fresh surfaces is blue to dark grey, buff and milky in color. 
The thickness of the dolomitic limestones beds ranges between $10 \mathrm{~cm}$ and $25 \mathrm{~cm}$ thick and may reach up to 1.0 meter thick. In this interval, there are also some marl beds which are characteristically olive-green in color and intercalated with dolomitic limestones. The very thin and stratified layers (millimeters in thickness) of mudstones were observed in the upper part of the middle section (Fig.3b). Moreover, part of this section is composed of intercalations of mudstones, limestone and dolomitic limestones. The box-work structure can be easily found in small and large scales in this interval (Fig. $3 b)$. The uppermost part of this interval is also characterized by a $10-15 \mathrm{~cm}$ thick bed of lithoclasts, which extends laterally throughout the outcrop. It may be resulted from storm deposits (Fig.3c). This bed can be used as a marker bed for correlation of the Baluti Formation with other locations.

The upper part (about $13.50 \mathrm{~m}$ thick) of the formation is lithologically more diverse. The thickness of beds is more varied and less mudstone is present. The thickness of the marl beds is varied as compared to the lower part. This interval is characterized by alternating thin, medium and thick beds of olive-green to dark-grey marl, marly limestone and medium to thickly bedded limestone and mudstone. The limestones are generally yellow and dark-grey in color and described as highly fractured, and containing calcitic veins and voids. The yellowish unit of limestones are characterized by the box-work structures (Fig.3d). In the topmost part, dolomitic limestones become more dominant, and are intercalated with mudstones and marls. At the top of the interval, there is a gradual transition into grey dolomites and dolomitic limestones of the overlying Sarki Formation (Fig.4).

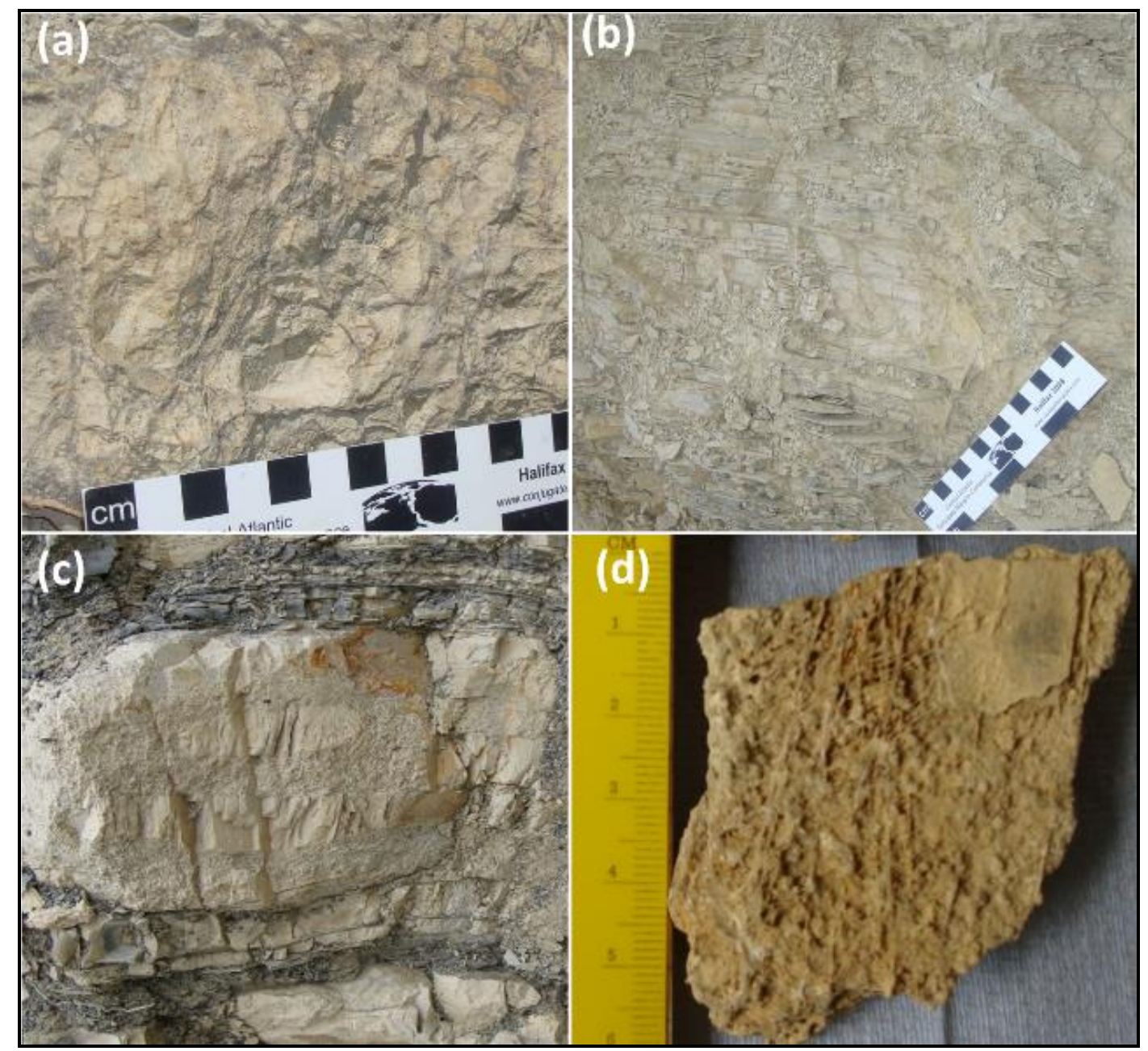

Fig. 3. (a) A broken piece of brecciated limestone, the voids are filled with yellowish clay, (b) the very thin and stratified layers (centimeters-millimeters in thickness) of mudstones, (c) a bed of lithoclasts of the Baluti Formation from uppermost part of the middle unit, (d) The box-work structure in a small scale in the upper unit of the Baluti Formation 


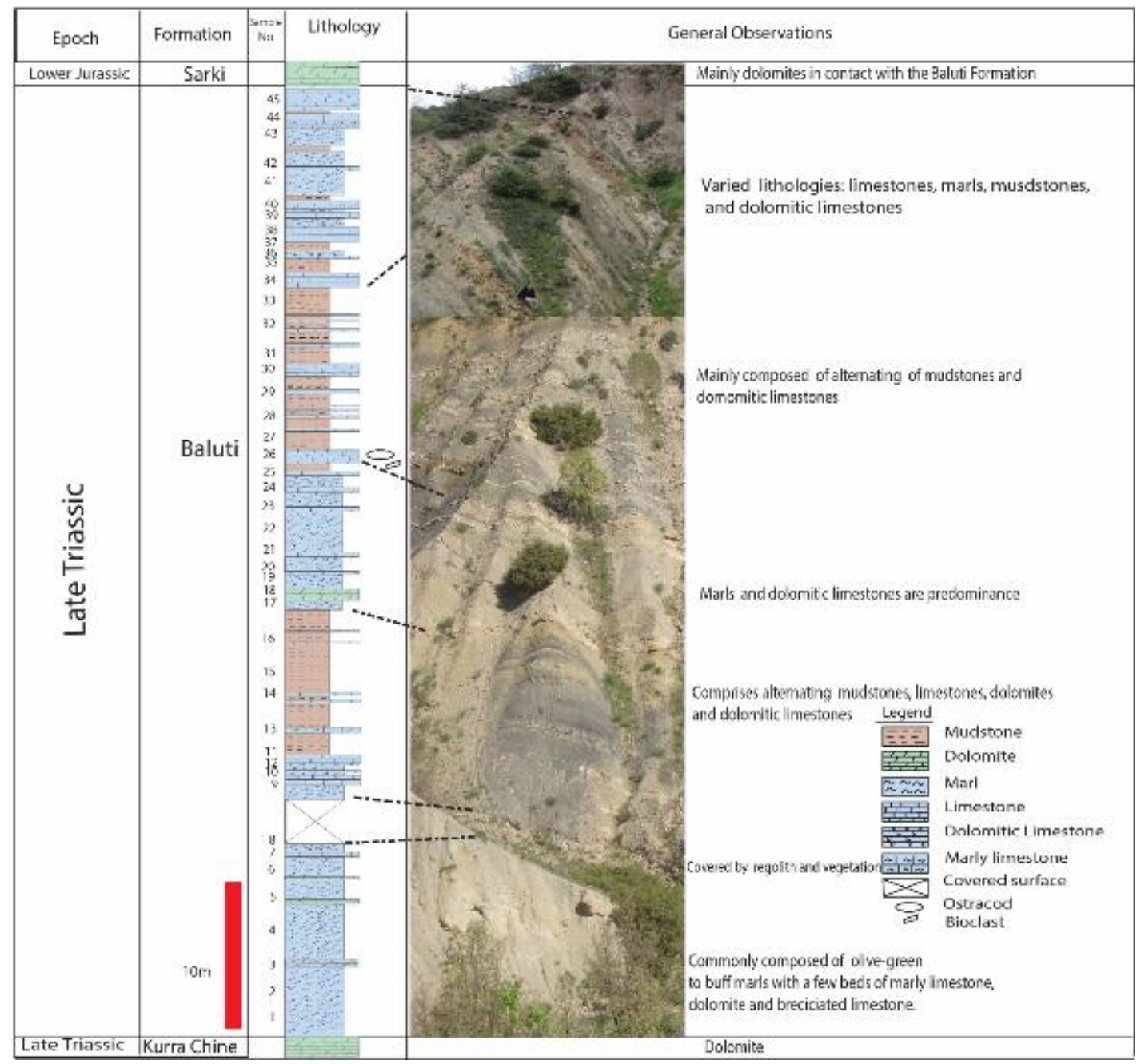

Fig.4. Lithostratigraphy of the Baluti Formation from Gara Anticline - Sarki section. The lower part is mainly composed of marls, while the middle part is mudstone dominant. The upper part is more diverse in lithology

\subsection{Microfacies Analysis}

To supplement field description of lithology microfacies analysis was performed using petrographic description of thin sections. The following microfacies are identified.

\subsubsection{Facies I: Finely Laminated dolomudstone}

These facies is commonly composed of buff to olive-green marls intercalated with medium bedded marly limestone and finely laminated dolostones. The microfacies displays very fine grains of dolomite (dolomicrite), and very small grains of the quartz. In this section, the facies exhibit light and dark layers' millimeters-thick. The light layers contain tiny quartz-grains that are silt-sized. The studied thin sections do not contain any fossils in this interval. The facies also contain very small pyrite grains and tiny particles of organic matter (Fig. 5a). Fine crystalline dolomicrite is found in intertidal and supratidal carbonates and is an early diagenetic product whose formation is described by sabkha evaporation models (Flügel, 2010). Parallel lamination takes place in supratidal, intertidal and subtidal environments, but is particularly abundant in the intertidal zone (Flügel, 2010). Marly limestones with no biota are suggested to be a feature of tidal flats (Aghaei et al., 2012). In the studied thin sections, no fauna was observed. This microfacies is also characterized by very thin dolomicrite (mudstone) with 
grains of detrital quartz, although in this case the proportion of carbonate is high. Mixed siliciclastic-carbonate rocks are common in near-coast environments (Flügel, 2010). Laminations in tidal flat sediments generally result from alternating spring or storm tide deposition (Shinn, 1983a). The occurrence of fine to medium quartz grains in a lime-mud matrix with rare or no show the proximity of a land area and clastic input, possibly from wind action reveals a deposition occurred under restricted lagoon environment (Farouk et al., 2018).

\subsubsection{Facies II: Fossil-barren lime mudstone}

The beds are dark grey to bluish in fresh surface, their thicknesses range from $10 \mathrm{~cm}$ up to $40 \mathrm{~cm}$. The facies is mainly composed of homogenized mudstone (microsparites) and there is no evidence of subaerial exposure such as fenestral structures or microcodium within the lime mudstone. However, in some cases the lime mudstone contains very rare tiny quartz grains, and the fractures and channels are infilled with calcite, organic matter. Overall, this microfacies comprises the homogenous micrite without fossil content and uncommon carbonate and non-carbonate grains. As with other facies, small $(0.5<\mu \mathrm{m})$ particles of the organic matter are present, but not common (Fig. $5 \mathrm{~b}$ ). Limestones deposited in lagoonal environment can be discriminated from open marine micritic carbonates by microfacies type and fossil content (Flügel, 2010). Normally, the open marine can be distinguished from the lagoonal environment by abundant and diverse fossils in open marine. Features, such as a limited number of grain types; the absence of reworked grains, rounding or sorting; and the lack of desiccation structures and microbial laminae and/or fenestral structures all indicate that sedimentation occurred in a low energy restricted shallow-subtidal environment (Rezaeian and Taheri, 2012). A low diversity of skeletal grains also suggests a restricted environment (Tucker and Wright, 1990). The absence of deep-water microfossils in the lime-mud may indicate an intertidal environment (Farouk et al., 2016). Moreover, the micritization process is an indicator of a low energy setting and lagoonal environment. The non-fossiliferous lime-mudstones facies/unit is believed to be produced in restricted lagoon setting (Tucker, 1985; Flügel, 2010)

\subsubsection{Facies III: Fenestral mudstone/packstone}

This facies comprises of medium and thick layers of dolomitic limestone (thicknesses of beds range between $30 \mathrm{~cm}$ to $100 \mathrm{~cm}$ ). The studied thin sections show that this facies is characterized by a fenestral fabric. The matrix comprises dolomicrite and micrite. The facies is not the same in all studied thin sections. Fenestrae can only be found in mudstone (dolomudstone), in which the fenestrae are filled with calcite. They may also be found within oolitic packstone, but in this case, they are not filled with calcite. This facies contains tiny particles of organic matter (Fig. 5C). Tidal carbonates are characterized by millimeter scaled lamination and fenestral pores (Flügel, 2010). Fenestral fabrics are important to Sedimentologists because they normally indicate peritidal deposition and sedimentation, which essentially occurs at sea level (Scholle and Ulmer-Scholle, 2003). Fenestral structures indicate low energy shallow water (Carević et al., 2013), and subsequent exposure in a tidal flat environment (Hardie, 1977). Horizontal fenestrae and fenestral structures are reported in recent supratidal sediments, which result from desiccation and shrinkage of lime mud during prolonged exposure (Shinn, 1968a; Shinn et al., 1969). Vaziri-Moghaddam et al. (2010) found that tidal flat sediments are fine-grained, lack fauna and have fenestrate structures. Within gypsum or banded anhydrite, cements sediment rarely infills birds-eye structures, vugs and fossils (Shinn, 1983b). As far for other facies, the prevalence of the fenestral structures indicates a tidal environment. Facies III shows these characteristics and is therefore tidal sedimentary facies. 

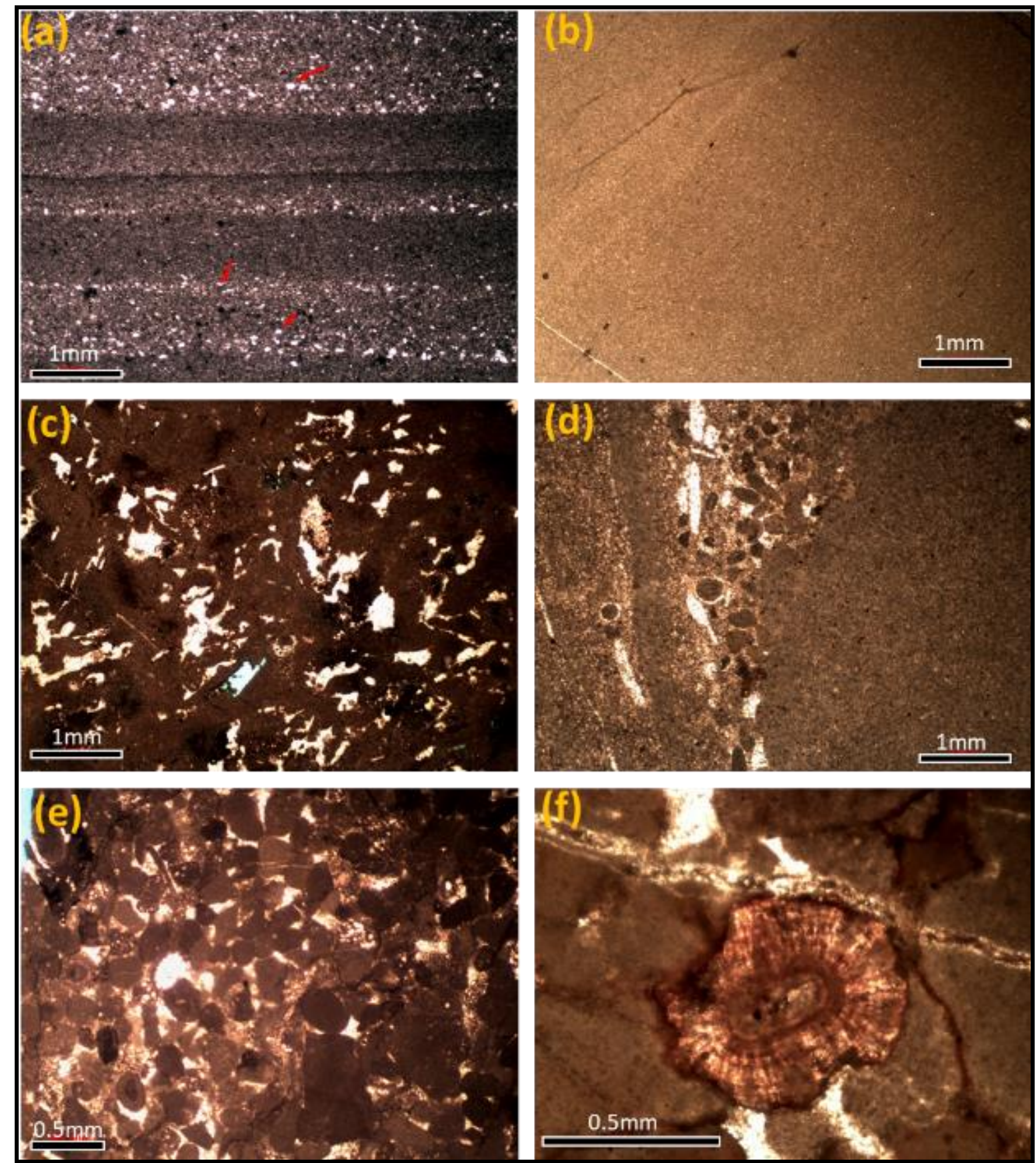

Fig.5. (a) Photomicrograph of finely laminated dolomicrite (Mudstone), fine light grey and millimetre thick layers. The light matrix contains very fine quartz grains (red arrows); (b) Photomicrograph of the homogenized mudstone, very fine-grained microsparite without any fossils or burrows structures; (c) Photomicrograph showing fenestral structures in dolomicrite, the fenestra is infilled with calcite;(d) Photomicrograph showing ooids and peloids, Ooids and peloids within micritic matrix, that appears as clusters rather than evenly distributed; (e) Lithoclasts within packstones in the Baluti Formation, this microfacies is characterized by common intraclasts, plant fragments and ooids; (f) An enlarged ooid grain (radial-fibrous) within lithoclasts

\subsubsection{Facies IV: Peloids and ooid wackestone}

These facies is characterized by dominance of peloids and ooids. These two components were not homogenously distributed within the studied thin sections, but were found as clusters within wackestones in micritic matrix. In these facies, it seems that most of the former ooids have been 
completely micritized, and no remnant structures are visible in these ooids (these grains may be peloids). However, some ooids have a clear and distinctive radial-fabric (Fig. 5d). Concentric ooids mainly originate in high energy environments such as shoals, tidal bars and beaches, while radial ooids are more common in a low energy setting like a restricted environment (e.g. lagoons, lagoonal ponds) (Flügel, 2010). Peloids can be found in shallow marine tidal and subtidal shelf carbonates, in reef, and mud-mounds, but can also be seen in deep-water carbonates (Flügel, 2010). The presence of individual ooids and peloids as grainstone-clasts and as clusters in wackestones, combined with the absence of fauna suggests storm deposits formed in a restricted environment. The micritic matrix of wackestones indicates a relatively quiet depositional environment.

\subsubsection{Facies V: Lithoclastic packstones}

Lithoclasts (intraclasts) with different shapes and sizes are common in these facies. Clasts are intensively packed together. In addition to lithoclasts, ooid grains [radial-fibrous (Fig. 5f)] and terrestrial or land-plant phytoclasts are found. There are very rare quartz grains in these facies. The size of the lithoclasts ranges from $1 \mathrm{~mm}$ up to $20 \mathrm{~mm}$. The clasts are less rounded, mostly angular, and are lime mudstones in lithology (Fig. 5e). Intraclasts were possibly eroded and mostly redeposited during storms occur in the supratidal flats and subtidal channels (Shinn, 1983a). Millimeter and centimeter sized intraclasts that are angular to rounded clasts of lime mudstones, packstone, bind stones and grainstones are common constituents of tidal carbonates. It is believed that these intraclastic packstone are related to storm wave erosion, and reworking of various sediment within shallow marine environments (Flügel, 2010). The input of terrigenous materials into the carbonate depositional environment can occur when the underlying sediments are eroded within the tidal zone (Flügel, 2010) and when the depositional environment is close to land. The angular grains and presence of ooids in these facies can point to a protected environment, affected by only infrequent storm. Intraclasts could be formed as a result of carbonate mud desiccation in supratidal environment (Flügel, 2010). Differences in shape, size, and orientation of the grains indicate an extensive reworking of semi-lithified sediment.

\subsection{Biomarkers Characteristics}

Biomarkers or biological markers are organic compounds in sediments, rocks, and crude oils in which those carbon structures can be traced back to a living organism. They are widely used to determine paleo depositional environment of the sediments (Hunt, 1996). In this study, the most common applied parameters of depositional related-biomarkers are used as a supplementary to the microfacies analysis for understanding paleoenvironment of the Baluti Formation.

\subsection{1. n-alkanes}

The gas chromatograms of the saturated hydrocarbons analyzed from the studied samples of Baluti Formation are shown in Fig. 6 with their related parameters in Table 1. In general, the $n$-alkanes are in the range of $\mathrm{C}_{15}$ to $\mathrm{C}_{32}$ from Gara Anticline. As shown in Table 1, the pristane/phytane ( $\mathrm{Pr} / \mathrm{Ph}$ ) ratios for most of sample are greater than one (1.2 in average). The $\mathrm{Pr} / \mathrm{Ph}$ ratio is widely used to deduce the depositional environment (oxic/anoxic) and the nature of the source of organic matter. The values of the $\mathrm{Pr} / \mathrm{Ph}$ less than 0.6 show the anoxic, the values between 1.25 and 2.13 may shows the anoxic to suboxic, whereas the values greater than the 3 display oxic environment (Peters et al., 2005). 

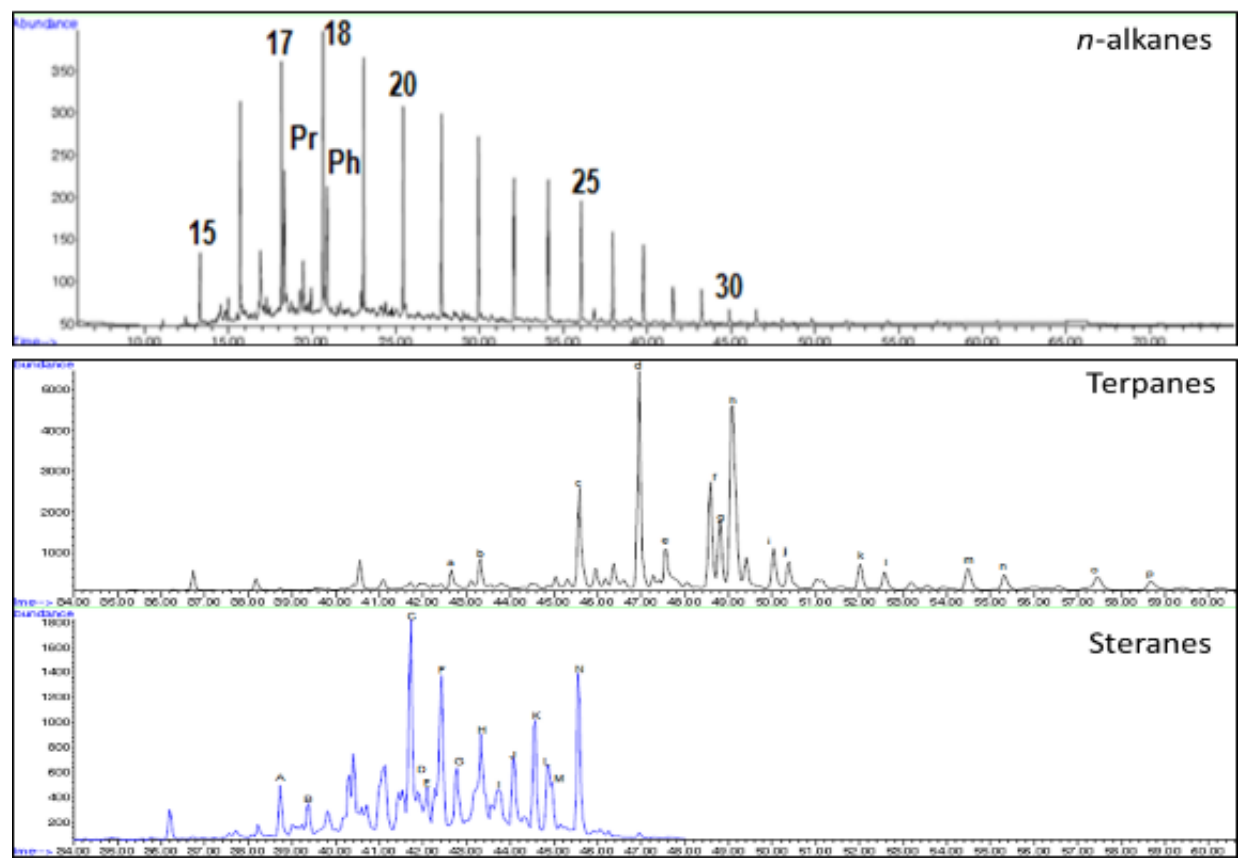

Fig.5. Gas Chromatographs of the $n$-alkanes and isoprenoids distribution $(\mathrm{m} / \mathrm{z} 85)$, of steranes $(\mathrm{m} / \mathrm{z}$ 217), and terpanes $(\mathrm{m} / \mathrm{z}$ 191) in Baluti sediments (a-Ts trisnorneohopane b-Tm trisnorhopane c-norhopane $\mathrm{d}-\mathrm{C}_{30}$ hopane e- $\mathrm{C}_{30}$ Moretane f-hopane $22 \mathrm{~S}$ g- $\mathrm{C}_{31}$ hopane $22 \mathrm{R}$, h-Gammaceranes i- $\mathrm{C}_{32}$ hopane $22 \mathrm{~S} \mathrm{j}-\mathrm{C}_{32}$ hopane $22 \mathrm{R} \mathrm{k}-\mathrm{C}_{33}$ hopane $22 \mathrm{~S}$ 1-hopane $22 \mathrm{R} \mathrm{m}-\mathrm{C}_{34}$ hopane $22 \mathrm{~S} \mathrm{n}-\mathrm{C}_{34}$ hopane $22 \mathrm{R}$ o- $\mathrm{C}_{35}$ hopane $22 \mathrm{~S}$ p- $\mathrm{C}_{35}$ hopane 22R., A- $\mathrm{C}_{27}$ Diacholestane 20S B- $\mathrm{C}_{27}$ Diacholestane 20R C-C $\mathrm{C}_{27}$ Cholestane 20S D-C $\mathrm{C}_{27}$ Cholestane 20R E- $\mathrm{C}_{27}$ Cholestane 20S F- $\mathrm{C}_{27}$ Cholestane 20R G-C 28 Ergostane 20S H-C 28 Ergostane 20R I-C 28 Ergostane 20S J-C 28 Ergostane 20R K-C 29 Stigmastane 20S L-C 29 Stigmastane 20R M- $\mathrm{C}_{29}$ Stigmastane $20 \mathrm{~S} N-\mathrm{C}_{29}$ Stigmastane $20 \mathrm{~S}$

Table 1. Results of GC-MS for the analyzed samples

\begin{tabular}{ccccccc}
\hline Samples & $\mathbf{P r} / \mathbf{P h}^{\boldsymbol{a}}$ & $\begin{array}{c}\text { Hopanes } \\
\mathbf{C}_{\mathbf{2 9}} / \mathbf{C}_{\mathbf{3 0}}\end{array}$ & $\begin{array}{c}\text { Steranes } \\
\mathbf{\%} \mathbf{C}_{\mathbf{2 7}}\end{array}$ & $\begin{array}{c}\text { Steranes } \\
\mathbf{\%} \mathbf{C}_{\mathbf{2 8}}\end{array}$ & $\begin{array}{c}\text { Steranes } \\
\mathbf{\%} \mathbf{C}_{\mathbf{2 9}}\end{array}$ & $\begin{array}{c}\text { Steranes } \\
\mathbf{C}_{\mathbf{2 9}} / \mathbf{C}_{\mathbf{2 7}}\end{array}$ \\
\hline Ba-Ga2 & 1.12 & 1.41 & 20 & 33 & 47 & 2.28 \\
Ba-Ga7 & 1.13 & 1.25 & 22 & 31 & 47 & 2.18 \\
Ba-Ga11 & 1.09 & 1.46 & 17 & 15 & 68 & 4.08 \\
Ba-Ga13 & 1.21 & 0.83 & 41 & 18 & 41 & 1.01 \\
Ba-Ga14 & 1.23 & 0.45 & 37 & 17 & 47 & 1.26 \\
Ba-Ga16 & 1.35 & 1.25 & 27 & 29 & 45 & 1.69 \\
Ba-Ga22 & 1.03 & 1.00 & 27 & 28 & 44 & 1.63 \\
Ba-Ga28 & 1.65 & 0.93 & 24 & 22 & 55 & 2.32 \\
Ba-Ga30 & 0.92 & 1.11 & 25 & 12 & 63 & 2.48 \\
Average & 1.2 & 1.1 & 27 & 23 & 51 & 2.1 \\
\hline
\end{tabular}

$\mathrm{a}=\mathrm{Pr} / \mathrm{Ph}$ : Pristane $/$ phytane,

$\mathrm{b}=\mathrm{Ts} /(\mathrm{Ts}+\mathrm{Tm})$ : Ts $18 \alpha(\mathrm{H}) 22,29,30$ trisnorneohopane / $(\mathrm{Ts} 18 \alpha(\mathrm{H}) 22,29,30$ trisnorneohopane + $\operatorname{Tm} 17 \alpha(\mathrm{H}) 22,29,30$ trisnorhopane)

\subsubsection{Terpanes (Hopanes)}

$\mathrm{C}_{30}$ hopane is associated with clay-rich source rock (Hakimi et al. 2014), while the dominance of $\mathrm{C}_{29}$ hopane indicates carbonate and evaporate (He et al.,2014). The $\mathrm{C}_{29}$ hopane (30-norhopane) is more dominant than $\mathrm{C}_{30}$ hopane in sediment of the Baluti Formation (Fig. 6 and Table 1). 


\subsubsection{Steranes}

The distribution of regular steranes of the studied samples shows that the ratios of $\mathrm{C}_{29} / \mathrm{C}_{27}$ are less than1.0. The dominance of $\mathrm{C}_{27}$ steranes is mainly derived from marine plankton, whilst the $\mathrm{C}_{29}$ steranes are often associated with higher plants (Peters et al. 2005) (Fig. 6 and Table 1). Regular Steranes $\mathrm{C}_{27}, \mathrm{C}_{28}$ and $\mathrm{C}_{29}$ distribution on ternary diagram could indicate quite similar depositional environments as that deduced from plotting the ratio of $\mathrm{C}_{29} / \mathrm{C}_{27}$ vs. isoprenoids (Fig. 7). Based on the distribution of regular steranes $\mathrm{C}_{29} / \mathrm{C}_{27}$ and isoprenoids $(\mathrm{Pr} / \mathrm{Ph})$, the sediments of Baluti from Gara section are characterized by land plant organic matter (Fig. 8).

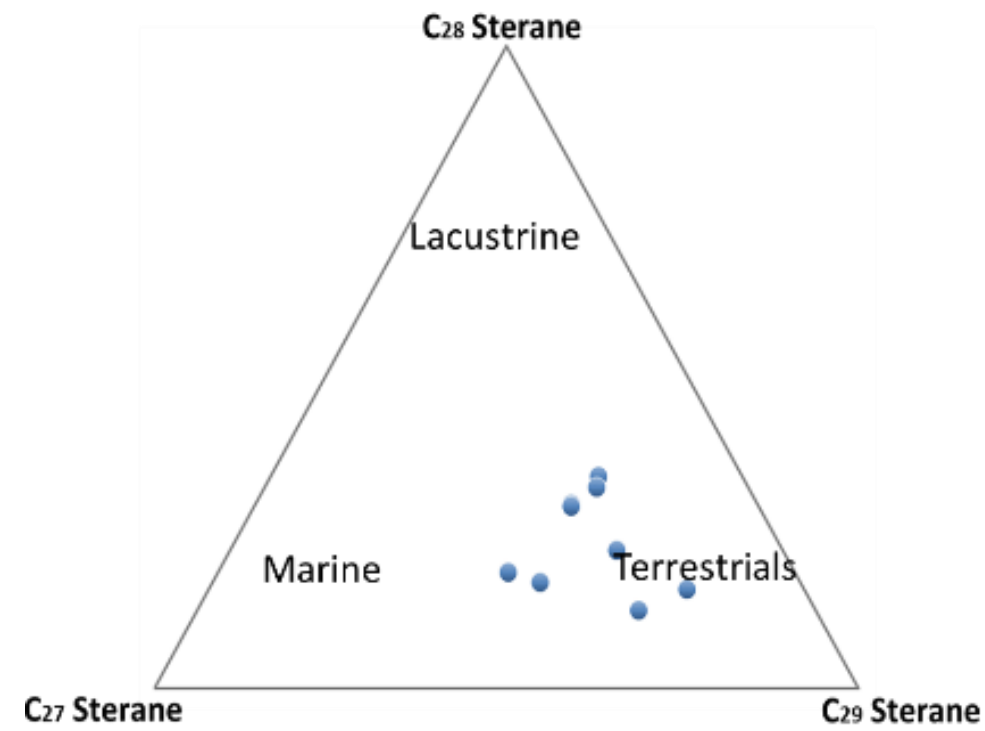

Fig. 7. The dominance of $\mathrm{C}_{27}$ steranes, mainly derived from marine plankton, whilst the $\mathrm{C}_{29}$ steranes are often associated with higher plants (Huang and Meinschein, 1979; Peters et al., 2005). Based on the distribution of regular steranes, the rocks of Baluti can be characterized by input of land plant organic matter (Terrestrials)

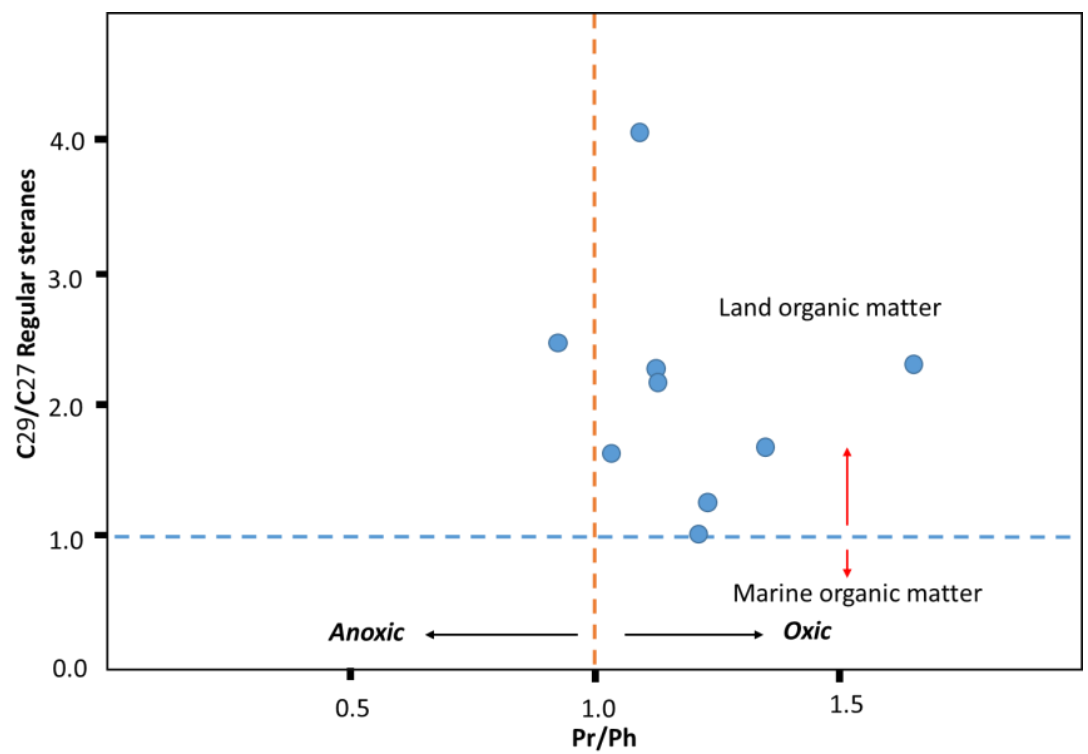

Fig.8. The distribution of regular steranes $\mathrm{C} 29 / \mathrm{C} 27$ and isoprenoids $(\mathrm{Pr} / \mathrm{Ph})$, the rocks of Baluti Formation from Gara section 


\section{Discussion}

Although the ratios of $\mathrm{Pr} / \mathrm{Ph}$ are considered as good indicators of depositional environment, caution should be taken into consideration since it is difficult to get at conclusive interpretations of redox conditions (Peters et al. 2005). As shown in Table 1, the values of $\mathrm{Pr} / \mathrm{Ph}$ are around one thus it is difficult to deduce a precise conclusion for the paleoenvironment of the Baluti Formation. However, the abundance of $\mathrm{C}_{29}$ over $\mathrm{C}_{27}$ steranes indicate a terrestrial source (Mohammed et al. 2020) in which by plotting of $\mathrm{C}_{29} / \mathrm{C}_{27}$ against isoprenoids ( $\mathrm{Pr} / \mathrm{Ph}$ ) a reasonable conclusion can be reached (Fig. 8). As mentioned earlier, several studies were carried out on the Baluti Formation. Al-Juboury and McCann (2010) studied petrologic and geochemical interpretation of a transitional Triassic-Jurassic using scanning electron microscopy, X-ray diffraction analysis, stable isotopes, and TOC analysis. They believed that the lower part of the formation was coastal-marine environment that was followed by shallower tidal flats and supratidal marginal-marine environments at the transitional boundary Sarki Formation. Tobia and Mustafa (2019) used chemical analysis of major and trace elements for determining the provenance and depositional environment of the Baluti Formation. Their results show tht the high ratios of $\mathrm{Mg} / \mathrm{Ca}$ for the Baluti Formation at Sarki area indicate near shore and shallow marine environment or intense diagenesis. Also, they concluded that carbonates of the Baluti Formation were precipitated from shallow marine water with input of the freshwater by the river. The U/Th, $\mathrm{V} / \mathrm{Cr}$, $\mathrm{V} / \mathrm{Sc}$, and $\mathrm{Cu} / \mathrm{Zn}$ ratios and negative Eu anomaly $(\mathrm{Eu} / \mathrm{Eu} * \mathrm{CN})$ reveal that the Baluti Formation sediments were deposited under oxic condition at Sarki section (Tobia and Mustafa, 2016). Shingaly, (2016) in his study on the lithology and diagenetic Processes of the Baluti Formation suggested a deep shelf environment for the formation. Al-Mashaikie et al. (2016) studied sedimentology of the Baluti Formation. They believe that the formation was deposited in distally steepened carbonate ramp/medial to distal slope environment (deep marine setting). The dolomites of the Baluti were formed as early diagenetic at the tidal-subtidal environment and as a late diagenetic at the shallow-deep burial depths (Al-Mashaikie and Razzak, 2017). Azo et al. (2020) studied the palynofacies analysis of the Baluti Formation in the Zewa section at Gara Anticline. Based on their findings, the paleoenvironmental deposition of the formation was probably shelf to basin transition and mud-dominated oxic shelf. As it is mentioned in above, different methods were used to evaluate the depositional setting of the Baluti Formation in which different conclusions were obtained. The findings of the current study are not in agreement with some published works. In this study, the biomarker characteristics in conjunction with evidence of microfacies analysis show that sediments of the Baluti Formation seem to be deposited in a supratidal environment and extended to low energy and restricted environment.

\section{Conclusions}

The petrographic investigation of the Baluti Formation enabled division into five microfacies namely; finely laminated dolomicrite, fossil-barren and lime mudstone, fenestral mudstone/packstone, peloids and ooids wackestone, and lithoclasts (intraclasts) grainstones. Based on these microfacies and biomarkers characteristics, the following depositional environments have been concluded:

- The occurrence of the mixed tiny quartz grains-carbonates and lime mudstone with no fauna reflecting a restricted lagoonal environment.

- The presence of a fenestral structure indicates a tidal environment of the Baluti Formation.

- Presence of the ooid as individual or as cluster combined with lack of fauna reflecting storm deposits formed in a restricted environment for the Baluti Formation.

- Millimeters and centimeters sized intraclasts with angular, rounded clast of lime mud indicated a tidal carbonate and supratidal environment for the studied formation.

- The high ratios of $\mathrm{C}_{17} / \mathrm{C}_{18}$ of $n$-alkane show oxic-suboxic environment for the Baluti sediments. 
- The abundance of $\mathrm{C}_{29}$ over $\mathrm{C}_{27}$ steranes indicates that the sediments of the Baluti Formation can be characterized by input of land plant organic matter.

\section{Acknowledgements}

The authors are grateful to Colin Taylor from the University of Aberdeen, Department of Geology and Petroleum Geology for his great assistance during analyzing the samples by GC-MS. The authors are very grateful to the Editor in Chief Prof. Dr. Salih M. Awadh, the Secretary of Journal Mr. Samir R. Hijab and the Technical Editors for their great efforts and valuable comments.

\section{References}

Asaad, I. S., Omer, M. F., 2019. Diagenetic history and porosity types of the Baluti Formation (Upper Triassic), Galley Derash, Duhok Governorate. Iraqi Bulletin of Geology and Mining, 15(2), 51-70.

Aghaei, A., Mahboubi, A., Moussavi-Harami, R., Heubeck, C., Nadjafi, M. 2013. Facies analysis and sequence stratigraphy of an Upper Jurassic carbonate ramp in the Eastern Alborz range and Binalud Mountains, NE Iran. Facies, 59(4), 863-889.

Al-Badry, A. M. S., 2012. Stratigraphy and geochemistry of Jurassic formations in selected sections -north Iraq; PhD Thesis, University of Baghdad. $162 \mathrm{pp}$.

Al-Juboury, A. I., McCann, T., 2013. Petrologic and geochemical interpretation of a transitional Triassic-Jurassic boundary sections from north Iraq. Iraqi Geological Journal, 50(2), 157-172.

Al-Mashaikie, S. Z. A., Abdul-Razzak, S. K., and Nasser, M. E., 2016. Sedimentology of the Baluti Formation in the Galley Derash, Amadiya, North Iraq: insight on carbonate turbidite facies and their depositional environmental. Arabian Journal Geoscience, 9: 723.

Aqrawi, A. A.M., Goff, J. C., Horbury, A. D., Sadooni, F. N., 2010. The Petroleum Geology of Iraq. Beaconsfield, United Kingdom, Scientific Press Ltd., 424pp.

Azo, N. M., Hanna, M. T., Edilbi, A. N. F., 2020. Paleoenvironmental interpretation of the Upper Triassic Baluti Formation in two selected sections at Amediya District, Kurdistan Region-Iraq: Insights from Palynofacies Study. Journal of Zankoy Sulaimani, 22 (1): 123-134.

Bellen, V. R. C., Dunnington, H.V., Wetzel, R., Morton, D., 1959. Lexique Stratigraphique International, Vol. III, Asie. In: Dubertret, L. (director), Fasc. 10c, Iraq, Center Nat. Researche Scientifique (Paris), 333pp.

Buday, T., 1980. The Regional Geology of Iraq, Vol.1: Stratigraphy and Palaeogeography. Publications of GEOSURVE., Baghdad, 445pp.

Carević, I., Khalil Abad, M.T., Ljubović-Obradović, D., Vaziri, S.H., Mirković, M., Aryaei, A.A., Stejić, P., and Ashouri, A.R., 2013. Comparisons between the Urgonian platform carbonates from eastern Serbia (Carpatho-Balkanides) and northeast Iran (Kopet-Dagh Basin): Depositional facies, microfacies, biostratigraphy, palaeoenvironments and paleoecology. Cretaceous Research, 40, 110-130.

De Vera, J., Gines, J., Oehlers, M. K., McClay, K., and Doski, J., 2009. Structure of the Zagros fold and thrust belt in the Kurdistan Region, northern Iraq. Trabajos de Geología, Universidad de Oviedo, 29: 213-217.

Dunham, R.H., 1962. Classification of Carbonate Rocks According to Depositional Texture. In: Ham, W.E., ed., Classification of Carbonate Rocks. American Association of Petroleum Geologists,1, 108-121.

Embry, A. F. and Klovan, J. E., 1971. A Late Devonian Reef Tract on Northeastern Banks Island, Northwest Territories. Canadian Petroleum Geology Bulletin, 19, 730-781.

English, J.M., Lunn, G.A., Ferreira, L., Yaku, G., 2015. Geologic evolution of the Iraqi Zagros, and its influence on the distribution of hydrocarbons in the Kurdistan Region. American Association of Petroleum Geologists Bulletin, 99(2), 231-272.

Farouk, S., Al-Kahtany, K., El-Sorogy, A., and Abd El-Motaal, E., 2018. High-frequency cycles and sequence stratigraphy of the lower Jurassic Marrat Formation, central Saudi Arabia. Marine and Petroleum Geology, 98, 369-383.

Farouk, S., Ahmed, F., Powell, J. H., and Marzouk, A., 2016. Integrated microfossil biostratigraphy, facies distribution and depositional sequences of the upper Turonian to Campanian succession in northeast Egypt and Jordan. Facies, 62, 8. 
Fouad, S. F., 2015. Tectonic map of Iraq, Scale 1: 1000 000, 3rd Edition. Iraqi Bulletin of Geology and Mining. $11(1), 1-7$.

Flügel, E., 2010. Microfacies of Carbonate Rocks-Analysis, interpretation and Application (2nd Edition). Springer-Verlag, Berlin, Heidelberg, 984 pp.

Hakimi, M. H., Abdullah, W. H., Shalaby, M. R., Alramisy, G.A., 2014. Geochemistry and organic petrology study of Kimmeridgian organic rich shales in the Marib-Shabowah Basin, Yemen: Origin and implication for depositional environments and oil-generation potential. Marine and Petroleum Geology, 50, 185-201

Hanna, M.T., 2007. Palynology of the Upper Part of Baluti Formation (Upper Triassic) and the Nature of its Contact with the Sarki Formation (Lower Jurassic) at Amadiya District, Northern Iraq: PhD Thesis, University of Mosul, Iraq, 143 pp.

Hardie, L.A.,1977. Sedimentation onthe modern carbonate tidal flats of Northwest Andros Island, Bahamas. John Hopkins University, Studies in Geology. 22, 224.

He, M., Graham, S., Scheirer, A.H., Peters, K. E., 2014. A basin modelling and organic geochemistry study in the Vallecitos syncline, San Joaquin Basin, California. Marine and Petroleum Geology, 79, 15-34

Hunt, J. M., 1996. Petroleum Geochemistry and Geology. Freeman and Company, San Francisco, 743p.

Huang, W.Y., Meinschein, W.G., 1979. Sterols as ecological indicators. Geochimica et Cosmochimica Acta, 43, $739-745$.

Jassim, S. Z, Buday, T., Cicha, I., Prouza, V., 2006. Late Permian-Liassic Megasequence AP6, Chapter 9. In: Jassim, S. Z, and Goff, J. (eds.), Geology of Iraq. Dolin, Prague and Moravian Museum, Brno, 71-183.

Lunn, G.A., Miller, S., Samarrai, A., 2019. Dating and correlation of the Baluti Formation, Kurdistan, Iraq: Implications for the regional recognition of a Carnian "marker dolomite", and a review of the Triassic to Early Jurassic sequence stratigraphy of the Arabian Plate. Journal of Petroleum Geology, 42(1), 5-36.

Mohammed, I.Q., Farouk, S., Baioumy, H., Lotfy, N.M., Al-Hadidy, A.H., 2020. Mineralogical and geochemical characteristics of the Paleozoic source rocks, Akkas gas field, Western Desert of Iraq: Implications for their origin, maturation and Ordovician-Silurian transition. Marine and Petroleum Geology, Volume 118,104432 .

Peters, K.E., Walters, C.C., Moldowan, J. M., 2005. The Biomarker Guide. Volumes 1 and 2, Cambridge University Press, 1155p.

Rezaeian, H.,Taheri, A., 2012. Biostratigraphy and depositional history of Coniacian-Santonian succession in East of Ramhormoz area (Tange-Bulfaris section). Journal of Geopersia 2(1), 41-53.

Scholle, P.A., Ulmer-Scholle, D.S, 2003. A Color Guide to the Petrography of Carbonate Rocks: American Association of Petroleum Geologists, 77, 474pp.

Shingaly, W. S., 2015. Lithology and diagenetic processes of the Baluti Formation (Upper Triassic) in the Amadiya Area, Kurdistan Region, Iraq. Journal of Zankoi Slemani, 17-2 (Part-A).

Shinn, E. A., 1968a. Practical significance of birds-eyes structures in carbonate rocks. Journal of Sedimentology and Petrology, 38(1), 215- 223.

Shinn, E. A., Lloyd, R.M., Ginsburg, R. N., 1969. Anatomy of a modern carbonate tidal-flat, Andros Island, Bahamas. Journal of Sedimentary Geology, 39 (3), 1202-1228.

Shinn, E. A., 1983a. Tidal flat. In: Scholle, A.P., Bebour, D.G., Moore, C.H. (eds.). Carbonate depositional environments. American Association of Petroleum Geologists, 33: 171-210.

Shinn, E. A., 1983b. Birds-eyes, fenestrae, shrinkage pores, and loferites: A reevaluation. Journal of Sedimentary Geology, 53(2), 619-628.

Tobia, F. H., Mustafa, B. H., 2016. Geochemistry and mineralogy of the Al-rich shale from Baluti Formation, Iraqi Kurdistan Region: implications for weathering and provenance. Arabian Journal of Geoscience, 9:757

Tobia, F. H., Mustafa, B. H., 2019. Provenance and depositional environment of the carbonates from Baluti Formation (Late Triassic), Kurdistan Region, Iraq. Iraqi Geological Journal, 52(2): 18-35.

Tucker, M. E., 1985. Shallow-marine carbonate and facies models. Geological Society, London, Special Publications, 18: 147-169.

Tucker, M. E., Wright, V.P., 1990. Carbonate Sedimentology. Blackwell Publications, Oxford, 482 pp.

Vaziri-Moghaddam, H., Seyrafian A., Taheri, A., Motiei, H., 2010. Oligocene-Miocene ramp system (Asmari Formation) in the NW of the Zagros basin, Iran: Microfacies, paleoenvironmental and depositional sequence. Revista Mexicana de Ciencias Geológicas, 27(1), 56-71. 